\title{
Partial rootzone drying: regulation of stomatal aperture and carbon assimilation in field-grown grapevines (Vitis vinifera cv. Moscatel)
}

\author{
Claudia R. de Souza ${ }^{\mathrm{A}, \mathrm{C}}$, João P. Maroco ${ }^{\mathrm{A}, \mathrm{B}}$, Tiago P. dos Santos ${ }^{\mathrm{C}}$, M. Lucília Rodrigues ${ }^{\mathrm{C}}$, \\ Carlos M. Lopes ${ }^{\mathrm{C}}$, João S. Pereira ${ }^{\mathrm{C}}$ and M. Manuela Chaves ${ }^{\mathrm{A}, \mathrm{C}, \mathrm{D}}$ \\ ${ }^{\mathrm{A}}$ Laboratório de Ecofisiologia Molecular, Instituto de Tecnologia Química e Biológica, \\ Apartado 127, Oeiras 2780-901, Portugal. \\ ${ }^{B}$ Instituto Superior de Psicologia Aplicada, Rua Jardim do Tabaco 34, Lisboa 1149-047, Portugal. \\ ${ }^{\mathrm{C}}$ Instituto Superior de Agronomia, Tapada da Ajuda, Lisboa 1349-017, Portugal. \\ DCorresponding author; email: mchaves@isa.utl.pt
}

\begin{abstract}
The effects of 'partial rootzone drying' (PRD) irrigation compared with other irrigation systems, namely non-irrigated (NI), full irrigation (FI) and deficit irrigation (DI), on stomatal conductance and carbon assimilation were evaluated in field-grown grapevines (Vitis vinifera $\mathrm{L}$. cv. Moscatel). At the end of the growing season, pre-dawn leaf water potential was highest in FI $(-0.18 \pm 0.01 \mathrm{MPa}$; mean \pm s.e. $)$, intermediate in PRD $(-0.30 \pm 0.01 \mathrm{MPa})$ and DI $(-0.36 \pm 0.02 \mathrm{MPa})$, and lowest in NI vines $(-0.64 \pm 0.03 \mathrm{MPa})$. Stomatal conductance measured under controlled conditions of light and temperature was reduced in NI ( $c a 60 \%)$ and PRD (ca 30\%) vines compared with DI and FI vines. Under ambient conditions, NI vines had lower rates of stomatal conductance ( ca 26\%), net $\mathrm{CO}_{2}$ assimilation ( $c$ a 28\%) and light-adapted PSII quantum yields ( $c a$ 47\%) than PRD, DI and FI vines. No significant differences were found among the three irrigated treatments. Both maximum electron transport rate $\left(J_{\max } ; c a 30 \%\right)$ and triose-phosphate utilization rates (TPU; $\left.c a 20 \%\right)$ were significantly lower in NI and PRD vines than in DI and FI vines. Carbon isotope composition $\left(\delta^{13} \mathrm{C}\right)$ of grape berries was highest in NI vines $(-24.3 \%)$, followed by PRD (-25.4\%o) and DI $(-25.8 \%)$ and lowest in FI (-26.4\%o) vines, suggesting a long-term increase in the efficiency of leaf gas exchange in NI compared with PRD, DI and FI vines. Sap-flow data and estimates of relative stomatal limitation are in accordance with the observed stomatal closure in PRD vines. In this study, we show that PRD irrigation was able to maintain a vine water status closed to FI, but with double water use efficiency, which was due to a reduction of stomatal conductance with no significant decrease in carbon assimilation.
\end{abstract}

Keywords: carbon isotope composition, fluorescence, gas exchange, partial rootzone drying, Vitis vinifera, water stress.

\section{Introduction}

For many regions with a Mediterranean climate, grapevine production depends upon water stored in soil during winter and spring. In summer, grapevines are often subjected to soil water deficits combined with high solar irradiance, high temperature and high vapour pressure deficit, which reduces leaf gas exchange and negatively affects grape yield and quality (Kliewer et al. 1983; Chaves and Rodrigues 1987; Schultz 1996). Stomatal closure appears to be the main cause for the decrease in the photosynthetic rate under mild drought conditions (Chaves 1991; Cornic 2000, Chaves et al. 2002). However, different reports also suggest the occurrence of non-stomatal effects on the reduction of photosynthesis, associated with the decrease in PSII efficiency and mesophyll metabolism, particularly when drought is associated with high light and temperature (Correia et al. 1990; Lu and Zhang 1999; Lawlor and Cornic 2002). In grapevines, non-stomatal effects on photosynthesis

Abbreviations used: $A$, net $\mathrm{CO}_{2}$ assimilation; $C_{\mathrm{a}}$, external $\mathrm{CO}_{2}$ partial pressure; $C_{\mathrm{i}}$, internal $\mathrm{CO}_{2}$ partial pressure; DI, deficit irrigation; ETR, electron transport rate through PSII; FI, full irrigation; $F_{\mathrm{m}}$ and $F_{\mathrm{m}}{ }^{\prime}$, the maximum chlorophyll fluorescence of dark- and light-adapted leaves, respectively; $F_{\mathrm{s}}$, steady-state chlorophyll fluorescence; $g_{\mathrm{s}}$, stomatal conductance; $J_{\max }$, maximum electron transport rate; NI; non-irrigated; NPQ, non-photochemical quenching; PPFD, photosynthetic photon flux density; PRD, partial rootzone drying; $R_{\mathrm{d}}$, mitochondrial respiration; RSL, relative stomatal limitation; TPU, triose-P utilization; $V_{\mathrm{Cmax}}$, maximum Rubisco activity; $\delta^{13} \mathrm{C}$, carbon isotope composition; $\Delta F$, variable fluorescence yield of light-adapted leaves; $\psi_{\mathrm{L}}$, pre-dawn leaf water potential; $\Phi_{\mathrm{PSII}}$, PSII efficiency for electron transport. 
occur when vines are subjected to drought under field conditions (Escalona et al. 1999; Maroco et al. 2002).

Roots of plants in a drying soil have the capacity to influence stomatal conductance in the absence of any change in water status owing to stomatal sensitivity to chemical signals produced in the drying roots (Zhang and Davies 1989a , 1989b; Tardieu et al. 1992; Croker et al. 1998; Davies et al. 2000). Increased water stress results in the release of $\mathrm{ABA}$ from root tips into the transpiration stream to the leaves, where it triggers stomatal closure (Davies and Zhang 1991; Davies et al. 1994).

Irrigation is currently used as a cultural practice to improve and standardize grapevine yield and quality (Battilani and Mannini 2000). However, irrigation has been considered a controversial practice in traditional viticulture because one of its major effects on grapevines is increased plant vigour. The use of assimilates for leaf growth restricts fruit set and development, whereas excessive leaf area can lead to excessive water loss, fungal diseases and shading of fruit, causing a reduction in fruit and wine quality (Smart et al. 1985; Dry et al. 1996; Dry and Loveys 1998). Dry et al. (1996) showed that watering only half the root system whilst keeping the other half dry can significantly restrict vegetative growth without affecting yield and grape quality. This irrigation technique is called 'partial rootzone drying' (PRD) (Loveys et al. 2000)

The hypothesis associated with PRD is based on the reduction of the stomatal conductance and growth caused by chemical signals, possibly ABA, synthesized by the roots in the drying zone and transported to the leaves in the transpiration stream (Loveys 1984; Gowing et al. 1990). Partial stomatal closure can lead to a decrease in transpiration and, possibly, an increase in water use efficiency (Bergmann et al. 1982; Düring et al. 1997; Turner 1997). However, the physiological response of grapevine, other than stomatal conductance, to PRD irrigation under natural field conditions has not received much attention. Also, in most cases PRD was compared with full irrigation treatments (absence of water deficits) and not with a system giving the same amount of water as PRD, as done in the present experiment.

We hypothesize that by triggering stomatal closure, PRD irrigation may prevent excessive water losses and lead to a better water balance in the long term. This effect may prevent the metabolic inhibition of $\mathrm{CO}_{2}$ assimilation that otherwise would occur if stress under field conditions was allowed to develop extensively (e.g. Escalona et al. 1999; Maroco et al. 2002). The aim of the present work was to analyse the effects of PRD on photosynthesis, stomatal conductance and water use efficiency (both in the short and long term) in field-grown grapevines. The contributions of stomatal and non-stomatal limitations to photosynthesis were studied by combined measurements of gas exchange and chlorophyll fluorescence. The physiological responses observed under PRD irrigation were compared with the ones observed under traditional drip irrigation systems, and in particular with the deficit irrigation (DI) treatment, where the same amount of water as in PRD was given to the whole root system.

\section{Materials and methods}

\section{Plant material and location}

The experiment was conducted during 2000 in a commercial vineyard located $70 \mathrm{~km}$ east of Lisbon, Portugal, at the Centro Experimental de Pegões. The climate is Mediterranean, with hot, dry summers and mild winters. The soil is derived from podzols, with a sandy surface layer $(0.6-1.0 \mathrm{~m})$ and clay at $1 \mathrm{~m}$ deep. We used Vitis vinifera $\mathrm{L}$. cv. Moscatel (syn. Muscat of Alexandria) grafted in 1997 to 1103 Paulsen rootstock. The grapevines were spaced $2.5 \mathrm{~m}$ between rows and $1.0 \mathrm{~m}$ within rows and trained on a vertical trellis with a pair of movable foliage wires for upwards shoot positioning. The vines were spur pruned on a bilateral Royat Cordon ( $\sim 16$ buds per vine).

\section{Irrigation and experimental design}

Irrigation water was applied with drip emitters, two per vine, operating at $4 \mathrm{~L} \mathrm{~h}^{-1}$ and positioned $30 \mathrm{~cm}$ from the vine trunk (out to both sides of the rows), distributed on both sides of the root system. The water was supplied according to the crop evapotranspiration (ETc) calculated from the evaporation of a Class A pan and corrected with the crop coefficients $\left(K_{\mathrm{c}}\right)$ proposed by Prichard (1992). The irrigation treatments were: rain-fed non-irrigated (NI); PRD $(50 \%$ of the ETc was supplied to only one side of the root system, alternating sides each $15 \mathrm{~d})$; DI ( $50 \%$ of the ETc was supplied to both sides of the vine); and full irrigation (FI; $100 \%$ of the ETc was supplied to both the sides of the root system). Irrigation was done twice per week from the beginning of berry development (June) until harvest (September). Cumulative rainfall for the experimental period was $33 \mathrm{~mm}$ and the amount of water applied in the irrigation treatments was $144 \mathrm{~mm}$ for FI and $72 \mathrm{~mm}$ for DI and PRD.

Fully developed leaves from adult vines were randomly chosen from a Latin square experimental design with the four irrigation treatments.

\section{Water relations}

Pre-dawn leaf water potential $\left(\psi_{\mathrm{L}}\right)$ was measured with a Scholandertype pressure chamber (Model 1000; PMS Instrument Co., Corvallis, OR, USA), at weekly intervals from the beginning of berry development until harvest. The measurements were done on six sunexposed and fully expanded leaves per treatments. Sap-flow measurements were done with a sap-flow system from Dynamax (Houston, TX, USA). Sap-flow sensors (SGA10 TYPE) were installed in main branches of representative vines, according to the manufacturer's instructions. Data were collected every $30 \mathrm{~min}$ throughout the growing season and recorded with a Campbell logger using the Flow 32 software supplied by the manufacturer. Sap-flow data were expressed on a leaf-area basis by dividing the sap flux density by the branch leaf area calculated in a non-destructive way, using a model with four variables - shoot length, leaf number, area of the largest and area of the smallest leaf - as described by Lopes and Pinto (2000).

\section{Gas exchange and chlorophyll fluorescence}

Daily net $\mathrm{CO}_{2}$ assimilation $(A)$, stomatal conductance $\left(g_{\mathrm{s}}\right)$, and $A-C_{\mathrm{i}}$ response curves (where $C_{\mathrm{i}}$ is the internal $\mathrm{CO}_{2}$ partial pressure) were measured on sun-exposed (at saturating light for photosynthesis) and recently fully mature leaves, with a portable Li-6400 infrared gas 
analyser (Li-Cor, Lincoln, NE, USA) with 4 replications per treatment for instantaneous measurements and 6-8 replications per treatment for $A-C_{\mathrm{i}}$ response curves. Response curves of net photosynthesis to internal $\mathrm{CO}_{2}\left(A-C_{\mathrm{i}}\right)$ were obtained with the same equipment with the leaf chamber temperature kept at $25^{\circ} \mathrm{C}$, photosynthetic photon flux density (PPFD) of $1200 \mu \mathrm{mol}$ photons $\mathrm{m}^{-2} \mathrm{~s}^{-1}$ and relative humidity at $60-70 \%$. The maximum rate of Rubisco carboxylation $\left(V_{\mathrm{Cmax}}\right)$, mitochondrial respiration $\left(R_{\mathrm{d}}\right)$, maximum electron transport capacity at saturating light $\left(J_{\max }\right)$ and the rate of triose-P utilization (TPU) were obtained by fitting the model of Farquhar et al. (1980) with modifications by Sharkey (1985) to $A-C_{\mathrm{i}}$ response curves, as described by Maroco et al. (2002) using the NONLIN procedure of SAS (version 8.0; SAS Institute, Cary, NC, USA). The limitation to photosynthesis imposed by closed stomatal conductance in treatments was estimated through the relative stomatal limitation (RSL, in percent) calculated from $A-C_{\mathrm{i}}$ response curves using the equation:

$$
\mathrm{RSL}=\left[\left(A_{\mathrm{Ci}=35 \mathrm{~Pa}}-A_{\mathrm{Ca}=35 \mathrm{~Pa}}\right) / A_{\mathrm{Ci}=35 \mathrm{~Pa}}\right] \times 100,
$$

where $A_{\mathrm{Ci}=35 \mathrm{~Pa}}$ is the net $\mathrm{CO}_{2}$ assimilation at an intercellular $\mathrm{CO}_{2}$ pressure of $35 \mathrm{~Pa}$, and $A_{\mathrm{Ca}=35 \mathrm{~Pa}}$ is the net $\mathrm{CO}_{2}$ assimilation at an ambient $\mathrm{CO}_{2}$ partial pressure $\left(C_{\mathrm{a}}\right)$ of $35 \mathrm{~Pa}$. Estimates of $A_{\mathrm{Ci}=35 \mathrm{~Pa}}$ were obtained from previously fitted $A-C_{\mathrm{i}}$ data to the equation:

$$
A=V_{\mathrm{C}}-0.5 V_{\mathrm{O}}-R_{\mathrm{d}}=V_{\mathrm{C}}\left(1-0.5 O / \tau C_{\mathrm{i}}\right)-R_{\mathrm{d}},
$$

where $V_{\mathrm{C}}$ and $V_{\mathrm{O}}$ are the rates of carboxylation and oxygenation of Rubisco, respectively, $R_{\mathrm{d}}$ is the mitochondrial respiration, $O$ and $C_{\mathrm{i}}$ are the oxygen and $\mathrm{CO}_{2}$ partial pressures in intercellular spaces, respectively, and $\tau$ is the specificity of Rubisco for $\mathrm{CO}_{2} / \mathrm{O}_{2}$ (Farqhuar et al. 1980).

Chlorophyll $a$ fluorescence was measured weekly from berry set to harvest with a Mini Pam fluorometer (H. Walz, Effeltrich, Germany), in the same leaves used for the daily courses of gas exchange. The photochemical efficiency of PSII $\left(\Phi_{\mathrm{PSII}}\right)$ was calculated as:

$$
\Phi_{\text {PSII }}=\left(F_{\mathrm{m}}{ }^{\prime}-F_{\mathrm{s}}\right) / F_{\mathrm{m}}{ }^{\prime},
$$

where $F_{\mathrm{m}}{ }^{\prime}$ is the maximum chlorophyll fluorescence of light-adapted leaves, and $F_{\mathrm{s}}$ is steady-state chlorophyll fluorescence. Nonphotochemical quenching (NPQ) was calculated as:

$$
\mathrm{NPQ}=\left(F_{\mathrm{m}}-F_{\mathrm{m}}{ }^{\prime}\right) / F_{\mathrm{m}}{ }^{\prime},
$$

where $F_{\mathrm{m}}$ is the maximum chlorophyll fluorescence of dark-adapted leaves. The electron transport rate (ETR) was calculated as:

$$
\mathrm{ETR}=\Delta F / F_{\mathrm{m}}{ }^{\prime} \times \mathrm{PPFD} \times 0.5 \times 0.84
$$

where $\Delta F$ is the variable fluorescence yield of light-adapted leaves $\left(F_{\mathrm{m}}{ }^{\prime}-F_{\mathrm{s}}\right)($ Björkman and Demmig 1987).

Carbon isotope composition

Samples for the determination of carbon isotope composition from mature leaves and grape berries were collected from four plants per treatment at harvest. The dried leaf (two mature leaves per plant) and berry samples ( 10 berries randomly taken from 200 berries sampled) were ground into a fine homogeneous powder and 1-mg subsamples were analysed for $\delta^{13} \mathrm{C}$ using a Europa Scientific ANCA-SL Stable Isotope Analysis System (Europa Scientific, Crewe, UK). Carbon isotope composition was expressed as $\delta^{13} \mathrm{C}=\left[\left(R_{\mathrm{S}}-R_{\mathrm{b}}\right) / R_{\mathrm{b}}\right] \times 1000$, where $R_{\mathrm{s}}$ is the ${ }^{13} \mathrm{C} /{ }^{12} \mathrm{C}$ ratio of the sample and $R_{\mathrm{b}}$ is the ${ }^{13} \mathrm{C} /{ }^{12} \mathrm{C}$ of the PDB (Pee Dee Belemnite) standard.

\section{Statistical data analysis}

Statistically significant effects were evaluated by one-way analysis of variance, and significant differences between treatments means were evaluated with Tukey's Honestly Significant Difference (HSD) tests with $\alpha=0.05$ by Statistica software (version 5.0, StatSoft, Tulsa, OK, USA). All measurements shown are the means \pm s.e.

\section{Results}

Seasonal evolution of water potential, gas exchange and maximum quantum yield of PSII

As illustrated in Fig. 1, pre-dawn leaf water potential $\left(\psi_{\mathrm{L}}\right)$ decreased in NI vines from July onwards, being significantly lower than the $\psi_{\mathrm{L}}$ of PRD, DI and FI vines. FI vines showed an almost constant $\psi_{\mathrm{L}}$, higher than $-0.2 \mathrm{MPa}$ throughout the growing season except for 9 and 16 August. During the season, PRD vines maintained water potential values close to those of FI vines. At the end of the season $\psi_{\mathrm{L}}$ was significantly lower in DI $(-0.30 \mathrm{MPa})$ than in PRD vines $(-0.21 \mathrm{MPa})$.

Non-irrigated vines showed the largest reductions in stomatal conductance and photosynthesis as the season progressed, reaching values below $0.10 \mathrm{~mol} \mathrm{H}_{2} \mathrm{O} \mathrm{m}^{-2} \mathrm{~s}^{-1}$ and $5 \mu \mathrm{mol} \mathrm{CO} \mathrm{CO}_{2}^{-2} \mathrm{~s}^{-1}$, respectively, in the middle of August. FI vines had the highest values, with $A$ between 12 and $14 \mu \mathrm{mol}$ $\mathrm{CO}_{2} \mathrm{~m}^{-2} \mathrm{~s}^{-1}$ and $g_{\mathrm{s}}$ between 0.3 and $0.5 \mathrm{~mol} \mathrm{H}_{2} \mathrm{O} \mathrm{m}^{-2} \mathrm{~s}^{-1}$. Statistically significant differences in photosynthesis and stomatal conductance were only observed between the irrigated treatments (FI, PRD and DI) and the non-irrigated treatment. Predawn values of $\Phi_{\mathrm{PSII}}\left(F_{\mathrm{v}} / F_{\mathrm{m}}\right.$, measured under dark-adapted conditions) remained close to 0.8 in all treatments throughout the season (Fig. 1).

\section{Diurnal course of gas exchange, chlorophyll fluorescence and sap flow}

Diurnal time courses of gas exchange and chlorophyll fluorescence parameters in a typical day in August are shown in Fig. 2. NI vines showed the lowest $A$ ( $c a$ 28\%) and $g_{\mathrm{s}}(\mathrm{ca} 17 \%)$ rates during the whole day. Differences between FI, PRD and DI vines were only observed at late afternoon, with FI vines exhibiting higher values of $A$ (around $13 \mu \mathrm{mol} \mathrm{CO} \mathrm{CO}_{2}^{-2} \mathrm{~s}^{-1}$ ) than PRD and DI vines (around $9 \mu \mathrm{mol} \mathrm{CO} \mathrm{Cm}^{-2} \mathrm{~s}^{-1}$ ). However, marked differences (around $0.10 \mathrm{~mol} \mathrm{H}_{2} \mathrm{O} \mathrm{m}^{-2} \mathrm{~s}^{-1}$ ) in stomatal conductance between the PRD and DI vines were apparent when measurements were taken under controlled conditions of light, temperature and $\mathrm{CO}_{2}$ (Fig. 3). Under those conditions, PRD and NI vines kept stomata more closed than DI and FI vines. The stomatal conductance was about $0.3 \mathrm{~mol} \mathrm{H}_{2} \mathrm{O} \mathrm{m}^{-2} \mathrm{~s}^{-1}$ in DI and FI vines, $0.24 \mathrm{~mol} \mathrm{H}_{2} \mathrm{O} \mathrm{m}^{-2} \mathrm{~s}^{-1}$ in PRD and $0.14 \mathrm{~mol} \mathrm{H}_{2} \mathrm{O} \mathrm{m}^{-2} \mathrm{~s}^{-1}$ in NI vines. Nevertheless, net photosynthesis was not lower in PRD vines than in FI and DI vines, being reduced only in NI vines ( $c a$ 27\%).

The decrease ( $\mathrm{ca} 70 \%$ ) of net photosynthesis rates observed in NI vines during the course of day was accompanied by a decrease ( $\mathrm{ca} 50 \%$ ) in quantum yield of PSII reaction centres and an increase of NPQ and ETR/A (Figs $2 b, d, f$ ). The NPQ reached values of 4.3 and the ETR/ $A$ increased to 46.5 in NI vines. Statistically significant differences between treatments were only observed by 1600 hours in the relative intrinsic water use efficiency 
$\left(A / g_{\mathrm{s}}\right)$. The $A / g_{\mathrm{s}}$ in PRD and NI vines was higher than $45 \mu \mathrm{mol} \mathrm{CO}_{2} \mathrm{~mol} \mathrm{H}_{2} \mathrm{O}^{-1}$, which contrasts with DI and FI vines where $A / g_{\mathrm{s}}$ was lower than $35 \mu \mathrm{mol} \mathrm{CO} \mathrm{CO}_{2} \mathrm{~mol}_{2} \mathrm{O}^{-1}$.

The daily transpiration measured with sap flow sensors on some days in August is shown in Fig. 4. The diurnal pattern of sap flow showed differences between all irrigation treatments on clear days. On sunny days, the FI vines showed greatest daily transpiration with sap flow rates higher than $300 \mathrm{~g} \mathrm{~h}^{-1} \mathrm{~m}^{-2}$. DI vines showed higher values of sap flow than PRD vines, whereas NI vines showed the lowest values (less than $100 \mathrm{~g} \mathrm{~h}^{-1} \mathrm{~m}^{-2}$ ).

\section{Modelled biochemical parameters from $A-C_{\mathrm{i}}$ curves}

Table 1 shows $V_{\text {Cmax }}, R_{\mathrm{d}}, J_{\max }$, TPU and RSL estimated from $A-C_{\mathrm{i}}$ response curves. Although $V_{\mathrm{Cmax}}$ and $R_{\mathrm{d}}$ were lower in $\mathrm{NI}$ and PRD vines than in FI and DI vines, the differences were not statistically significant $(P<0.05)$ owing to the high variability observed in these estimates. $J_{\max }$ was significantly lower in NI and PRD vines (125-136 $\left.\mu \mathrm{mol} \mathrm{m}^{-2} \mathrm{~s}^{-1}\right)$ than in FI and DI vines $\left(170-180 \mu \mathrm{mol} \mathrm{m}^{-2} \mathrm{~s}^{-1}\right)$. TPU estimated from the $A-C_{\mathrm{i}}$ curves was decreased ( $c a$ 25\%) in $\mathrm{NI}$ and PRD vines compared with DI and FI vines. However, the difference between PRD and DI was not statistically significant. Finally, the relative stomatal limitation of photosynthesis increased from $24 \%$ in FI and DI vines to $29 \%$ in PRD and $38 \%$ in NI vines. However, no significant differences were observed in RSL estimates for the irrigated treatments.

\section{$\delta^{13} \mathrm{C}$ in leaves and grape berries}

The $\delta^{13} \mathrm{C}$ measured in the leaves and berries collected at harvest was correlated $\left(r^{2}=0.68, P<0.05\right)$ with $\Psi_{\mathrm{L}}$ measured at the end of the dry season (August 2000), which was used as a water stress indicator (Figs $5 a, b$ ). For leaves, statistically significant differences for $\delta^{13} \mathrm{C}$ were observed only between the irrigated (average for the three irrigated treatments, $-27 \%$ ) and the non-irrigated treatments $(-25 \%)$ (Fig. 6a). However, in grape berries, the $\delta^{13} \mathrm{C}$ was significantly lower in PRD $(-25 \%)$ than FI $(-26 \%)$ vines, whereas there were no differences between DI and FI vines (Fig. 6b).

\section{Discussion}

Irrigation using the partial rootzone drying technique allowed vines to maintain a higher water status than the conventional deficit irrigation. In PRD, $\Psi_{\mathrm{L}}$ remained closer

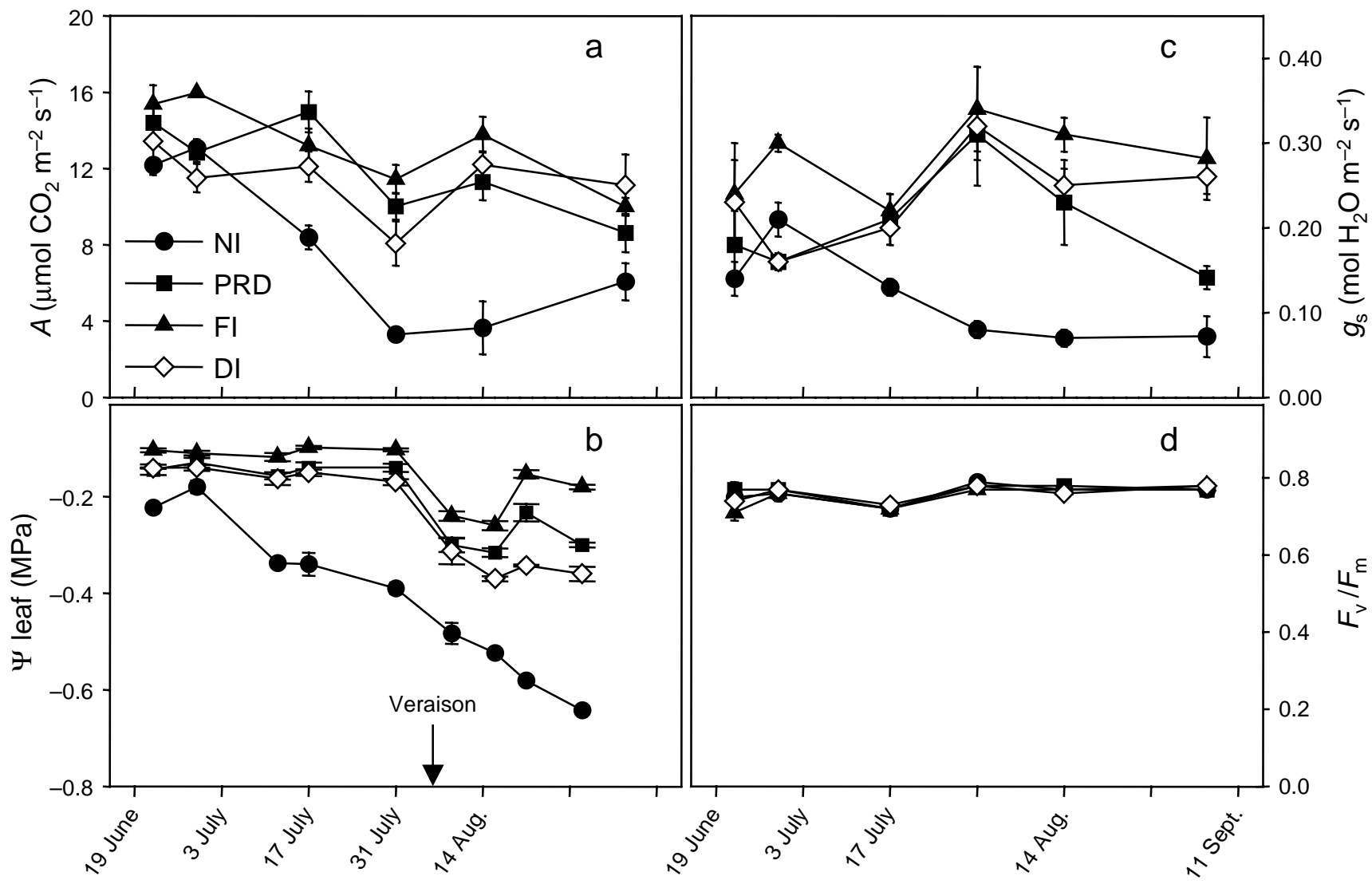

Date

Fig. 1. Seasonal trends of $(a)$ photosynthesis $(A),(b)$ pre-dawn water potential $\left(\Psi_{\mathrm{L}}\right),(c)$ stomatal conductance $\left(g_{\mathrm{s}}\right)$ and $(d)$ efficiency of excitation capture by open PSII in dark-adapted leaves $\left(F_{\mathrm{v}} / F_{\mathrm{m}}\right) . A$ and $g_{\mathrm{s}}$ are maximal values measured at 1400 hours. Values are means \pm s.e. 
to the FI vines than to the DI vines (Fig. 1). These results indicate that PRD vines reduced transpiration and stomatal conductance compared with DI vines, in spite of the same amount of water supplied. This was observed in the late afternoon in the diurnal course, as well as in the measurements done under controlled conditions of $\mathrm{CO}_{2}$, light and temperature (Figs 2, 3). Furthermore, these results are supported by sap flow measurements, which reflect water use over a longer term. The lower sap-flow rates in PRD vines than in DI vines suggest a stronger reduction of stomatal conductance in PRD vines (Fig. 4). These results support the hypothesis postulated by Loveys et al. (2000) that PRD decreases stomatal conductance, presumably as a result of the production of chemical signals in dehydrating roots. Stoll et al. (2000) observed an increase of ABA concentration in xylem sap originated by roots in contact with dry soil and also an increase of xylem sap $\mathrm{pH}$, which are known to promote stomatal closure under water stress conditions (Davies et al. 2000). As expected, the differences that we found between PRD and DI are much more subtle than those observed between PRD and FI. Indeed, large differences have been reported between PRD and FI-type treatments by Stoll et al. (2000) and Dry et al. (2000).

Statistically significant reductions in photosynthesis as the season progressed were observed only in NI vines. This decrease in $A$ was accompanied by reductions in stomatal

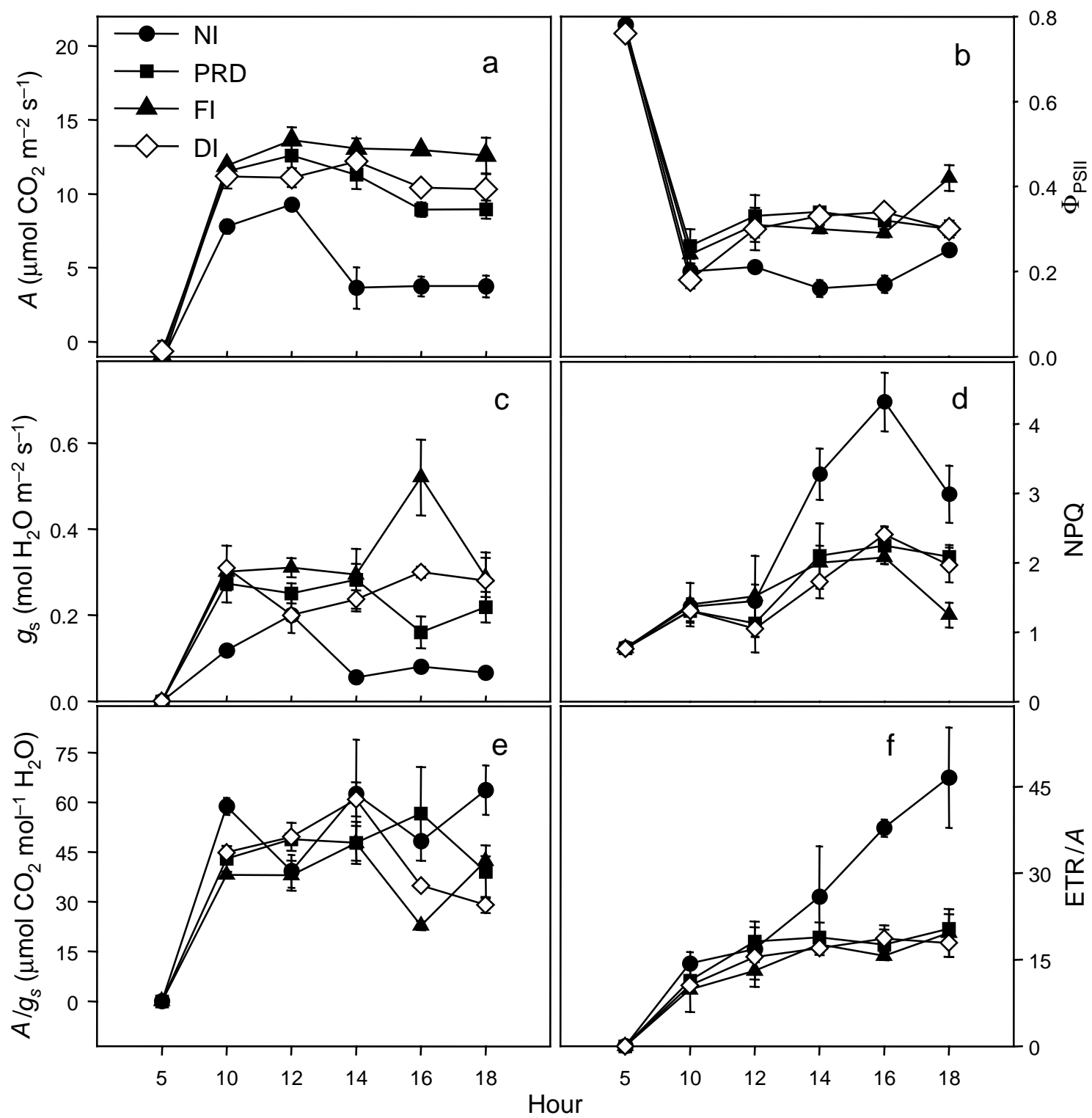

Fig. 2. Daily courses of $(a)$ photosynthesis $(A),(b)$ quantum yield of PSII $\left(\Phi_{\mathrm{PSII}}\right),(c)$ stomatal conductance $\left(g_{\mathrm{s}}\right),(d) \mathrm{NPQ}$, $(e)$ intrinsic water use efficiency $\left(A / g_{\mathrm{s}}\right)$ and $(f)$ the ratio ETR/A. The measurements were done on 14 August (one week after veraison). Values are means \pm s.e. 


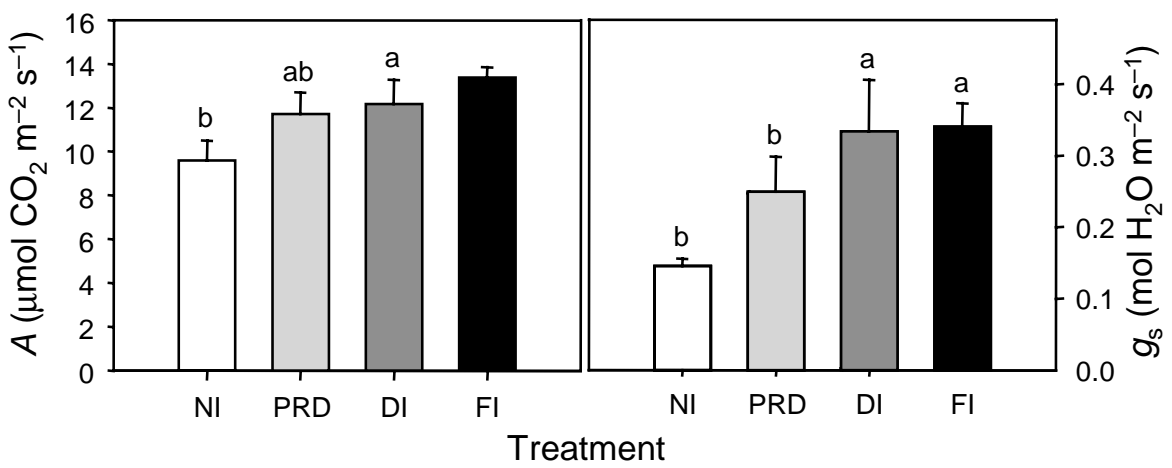

Fig. 3. Photosynthesis $(A)$ and stomatal conductance $\left(g_{\mathrm{s}}\right)$ in $\mathrm{cv}$. Moscatel under controlled conditions: $350 \mu \mathrm{mol} \mathrm{mol} \mathrm{m}^{-1} \mathrm{CO}_{2}, 1200 \mu \mathrm{mol} \mathrm{m} \mathrm{m}^{-2} \mathrm{~s}^{-1}$ PPFD and $25^{\circ} \mathrm{C}$ leaf temperature. Measurements were done at the end of August. Values are means \pm s.e. Different letter suffixes show statistically significant differences at $\alpha=0.05$.

conductance and in $\Phi_{\mathrm{PSII}}$, suggesting a downregulation of photosynthesis to match the decreased $\mathrm{CO}_{2}$-assimilation capacity under water stress conditions. However, no photoinhibition (as estimated by pre-dawn $F_{\mathrm{v}} / F_{\mathrm{m}}$ ) was observed (Fig. 1). These results are in accordance with reports of high tolerance of the photochemical apparatus of grapevine leaves under environmental stress (Gamon and Pearcy 1990; Chaumont et al. 1995), including drought (Flexas et al. 1999a, 1990b; Maroco et al. 2002). The major process involved in protection against photodamage during water stress is probably the increase of non-photochemical energy dissipation, as we observed in NI vines (Fig. 2). This results in the reduction of the quantum yield of PSII photochemistry but allows the maintenance of a balance with electron flow requirements for carbon metabolism (Weis and
Berry 1987; Krause and Weis 1991). Furthermore, the increased ETR/ $A$ ratio also observed in NI vines indicates that at least some of the electrons are not used directly in $\mathrm{CO}_{2}$ assimilation but rather in other processes such as photorespiration, which has been reported to increase under drought (Leegood 1995; Flexas et al. 1999b). These responses in grapevines play an important role in the regulation between the photochemical and the carbon assimilation reactions under water stress, as in other species adapted to Mediterranean climates (Quick et al. 1992).

Rubisco activity, RuBP regeneration and metabolism of triose-P are three major metabolic steps identified as important for optimal photosynthetic performance. It is noteworthy that the maximum Rubisco activity $\left(V_{\mathrm{Cmax}}\right)$ was not statistically significantly different among treatments

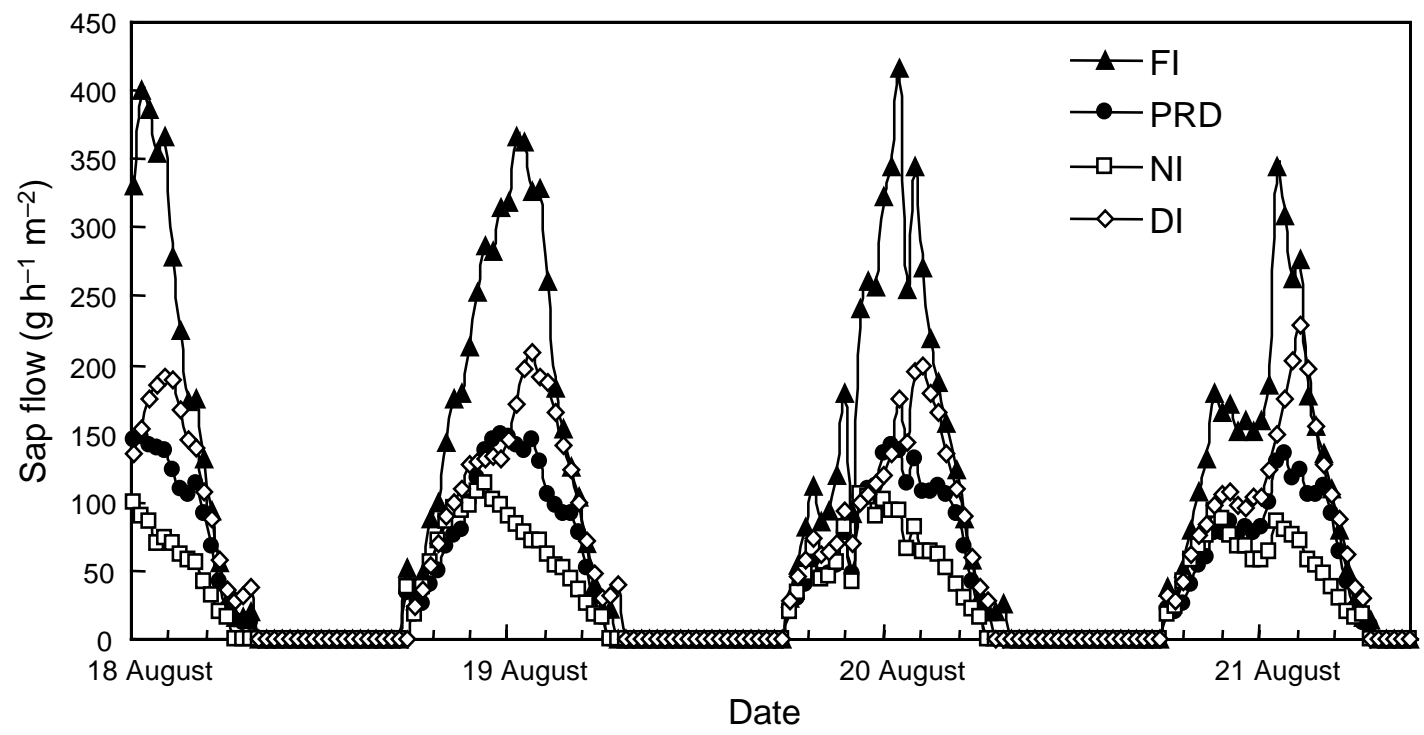

Fig. 4. Diurnal course of sap flow per unit leaf area on different water treatments. Measurements were done during a week in August 2000. 
Table 1. Estimated model parameters $\left(V_{\mathrm{Cmax}}, J_{\max }\right.$, TPU and $\left.\boldsymbol{R}_{\mathrm{d}}\right)$ and RSL for the irrigation treatments Values are means \pm s.e. Different superscript letters show statistically significant differences at $\alpha=0.05$

\begin{tabular}{lccccc}
\hline Treatment & $\begin{array}{c}V_{\text {Cmax }} \\
\left(\mu \mathrm{mol} \mathrm{m} \mathrm{m}^{-1}\right)\end{array}$ & $\begin{array}{c}J_{\max } \\
\left(\mu \mathrm{mol} \mathrm{m} \mathrm{m}^{-2} \mathrm{~s}^{-1}\right)\end{array}$ & $\begin{array}{c}\text { TPU } \\
\left(\mu \mathrm{mol} \mathrm{m}^{-2} \mathrm{~s}^{-1}\right)\end{array}$ & $\begin{array}{c}R_{\mathrm{d}} \\
\left(\mu \mathrm{mol} \mathrm{m} \mathrm{m}^{-1}\right)\end{array}$ & $\begin{array}{c}\text { RSL } \\
(\%)\end{array}$ \\
\hline NI & $44.92 \pm 4.82^{\mathrm{a}}$ & $125.18 \pm 5.03^{\mathrm{a}}$ & $7.48 \pm 0.24^{\mathrm{a}}$ & $1.94 \pm 0.99^{\mathrm{a}}$ & $38 \pm 0.03^{\mathrm{a}}$ \\
PRD & $46.09 \pm 3.67^{\mathrm{a}}$ & $136.62 \pm 6.03^{\mathrm{a}}$ & $8.24 \pm 0.40^{\mathrm{ab}}$ & $2.76 \pm 0.80^{\mathrm{a}}$ & $29 \pm 0.02^{\mathrm{ab}}$ \\
DI & $53.63 \pm 6.69^{\mathrm{a}}$ & $171.09 \pm 13.34^{\mathrm{b}}$ & $9.79 \pm 0.61^{\mathrm{bc}}$ & $4.12 \pm 1.52^{\mathrm{a}}$ & $23 \pm 0.03^{\mathrm{b}}$ \\
FI & $54.91 \pm 3.38^{\mathrm{a}}$ & $180.35 \pm 15.65^{\mathrm{b}}$ & $9.99 \pm 0.52^{\mathrm{c}}$ & $3.89 \pm 0.75^{\mathrm{a}}$ & $24 \pm 0.01^{\mathrm{b}}$ \\
\hline
\end{tabular}

(although there was a trend for lower $V_{\mathrm{Cmax}}$ in NI vines than in FI vines), whereas RuBP regeneration (which is proportional to $J_{\max }$ ) was significantly lower in NI and PRD than in DI and FI vines. This is in accordance with the decrease in the quantum yield of PSII photochemistry observed in NI, allowing the adjustment of electron flow to the limited carbon uptake as a result of stomatal closure. This could also be related to the high sensitivity of photophosphorylation to leaf water deficit as reported by Giménez et al. (1992). However, Rubisco activity seems to be more resistant to water stress than photophosphorylation, with significant effects occurring only for severe drought. In studies with grapevine, Escalona et al. (1999) did not observe a significant reduction in Rubisco carboxylation efficiency for $\Psi_{\mathrm{L}}$ of $-0.5 \pm 0.04 \mathrm{MPa}$, while Maroco et al. (2002) observed a significant reduction of $V_{\mathrm{Cmax}}$ for $\Psi_{\mathrm{L}}$ of $-0.95 \pm 0.01 \mathrm{MPa}$ in the same cultivar. In contrast, TPU capacity was significantly reduced in both NI and PRD vines compared with FI vines. Drought can cause a decline of TPU due to diminished supply of inorganic phosphate to the Calvin cycle, consistent with a slow-down in growth generally observed in drought-stressed plants (Chaves 1991). Statistically significant growth inhibition was indeed observed in NI and PRD vines (see dos Santos et al. 2003). Although no

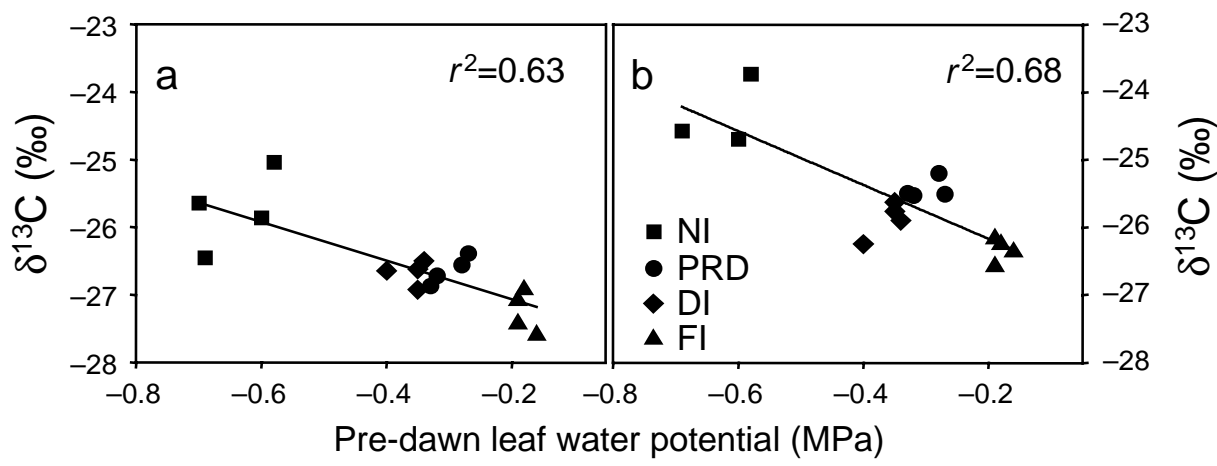

Fig. 5. Relationship between pre-dawn leaf water potential recorded at the end of August and $\delta^{13} \mathrm{C}$ measured in leaves $(a)$ and grape berries $(b)$ at harvest in September. $\left(r^{2}\right.$ is significant at $\alpha=0.05$.)

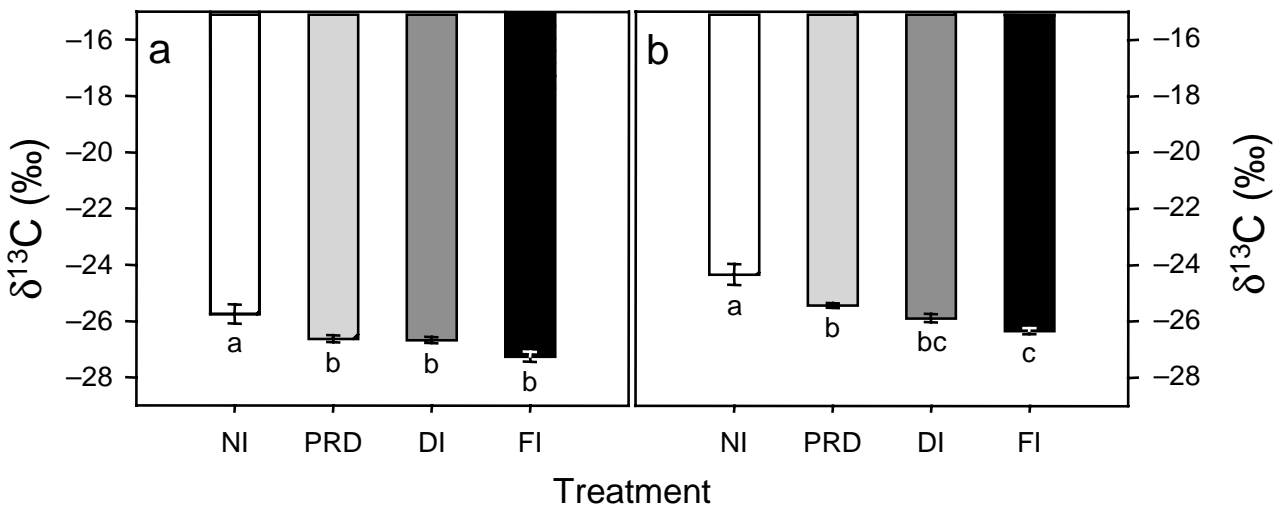

Fig. 6. Effects of different water treatments on isotope composition $\left(\delta^{13} \mathrm{C}\right)$ of leaves $(a)$ and grape berries (b) sampled at harvest in September. Values are means \pm s.e. Different letter suffixes show statistically significant differences at $\alpha=0.05$. 
significant differences were found between irrigated treatments, PRD and NI vines showed an increase of RSL of photosynthesis, indicating that stomatal conductance was more reduced than in DI and FI vines. The increased RSL of photosynthesis in NI and PRD vines confirms the results of $A$ and $g_{\mathrm{s}}$ measured under controlled conditions.

One of the main effects of cultivating grapevines under PRD was reported to be an improvement of water use efficiency (Dry et al. 1996; Loveys et al. 2000). In the present study we measured the carbon isotope composition $\left(\delta^{13} \mathrm{C}\right)$ of leaves and grape berries to evaluate the long-term water use efficiency in the different treatments. The $\delta^{13} \mathrm{C}$ is an integrative indicator of the relative efficiency of $\mathrm{CO}_{2}$ assimilation to water loss and reflects the long-term effect of the plant water status throughout the growth season. It is related to the ratio of intercellular and atmospheric $\mathrm{CO}_{2}$ concentrations $\left(C_{\mathrm{i}} / C_{\mathrm{a}}\right)$ and is therefore dependent on both $A$ and $g_{\mathrm{s}}$ (Farquhar et al. 1982). It is well documented that water stress changes water use efficiency and carbon isotope composition in different species (Farquhar and Richards 1984; Osório et al. 1998). In grapevines, Gibberd et al. (2001) observed a negative linear relationship between transpiration efficiency and ${ }^{13} \mathrm{C}$ discrimination. The decrease in stomatal conductance is reflected in an increase of $\delta^{13} \mathrm{C}$ due to the reduced discrimination by Rubisco (Farquhar et al. 1982). Our results have shown that $\delta^{13} \mathrm{C}$ of tissue samples were affected by plant water deficit (Fig. 5). The carbon isotope composition of grape berries suggests increased stomatal control and therefore increased water use efficiency at the leaf level in NI and PRD vines as compared with FI and DI vines (Fig. 6). The higher $\delta^{13} \mathrm{C}$ in grape berries than in leaves may be due to the fact that the carbon laid down in the leaves occurs early in the season when stress is mild and differences in stomatal conductance between treatments are not so marked or are even absent. In contrast, carbon in the berries was derived from photosynthesis occurring after veraison when the stress effects were more accentuated. That is, berry tissue may have originated from photoassimilates with a less negative $\delta^{13} \mathrm{C}$. In addition, the high accumulation of malic acid in the immature berries probably occurs through $\beta$-carboxylation of phosphoenolpyruvate by PEP carboxylase (Di Marco et al. 1977), which favours ${ }^{13} \mathrm{C}$ (Farquhar and Richards 1984; Brugnoli and Farquhar 2000).

In conclusion, PRD irrigation was able to maintain a vine water status closer to that of fully irrigated vines. This was the result of decreased stomatal conductance with no depressive impact on carbon assimilation. This led to increased intrinsic water use efficiency and increased longterm water use efficiency. While the benefits of PRD relative to NI (increased $\mathrm{CO}_{2}$ assimilation) and to FI (increased water use efficiency) were obvious, from a strictly physiological point of view differences between the PRD and DI treatments were subtle. Nevertheless, vegetative growth, as measured by leaf area and pruning weight, was significantly affected as described in a companion study (dos Santos et al. 2003). Whether this is sufficient to recommend this practice at the commercial level, at least under conditions of moderate drought as those prevailing in this experiment, will depend on the integrated effects on vegetative growth (with impact on microclimate) and fruit quality. However, this is an area where much research is still needed to evaluate the relative PRD benefits compared with traditional irrigation techniques under different environmental conditions: over several years and with different levels of soil and atmosphere water stress.

\section{Acknowledgments}

The financial support from EU project IRRISPLIT (ICA3-CT-1999-00008) is acknowledged. C.R.S. was a recipient of a doctoral fellowship granted by Fundação para Ciência e Tecnologia (PRAXIS XXI/BD/21856/99). We also thank A. Rodrigues and E. Breia for technical support in the field experiment.

\section{References}

Battilani A, Mannini P (2000) Grapevine (Vitis vinifera) yield and quality response to irrigation. In 'Proceedings of the third international symposium on irrigation of horticultural crops'. Acta Horticulturae 537, 895-902.

Bergmann H, Roth D, Augsten H, Schwarz K (1982) The influence of temporary water deficit on the water use efficiency of crops, especially spring barley. Archiv für Acker-und Pflanzenbau und Bodenkunde 26, 217-225.

Björkman O, Demmig B (1987) Photon yield of $\mathrm{O}_{2}$ evolution and chlorophyll fluorescence characteristics at $77 \mathrm{~K}$ among vascular plants of diverse origins. Planta 170, 489-504.

Brugnoli E, Farquhar GD (2000) Photosynthetic fractionation of carbon isotopes. In 'Photosynthesis: Physiology and Metabolism. Advances in Photosynthesis Vol. 9'. (Eds RC Leegood, TD Sharkey and $\mathrm{S}$ von Caemmerer) pp 399-434. (Kluwer Academic: Dordrecht)

Chaumont M, Morot-Gaudry JF, Foyer C (1995) Effects of photoinhibitory treatment on $\mathrm{CO}_{2}$ assimilation, the quantum yield of $\mathrm{CO}_{2}$ assimilation, D1 protein, ascorbate, glutathione and xanthophyll contents and the electron transport in vine leaves. Plant, Cell and Environment 18, 1358-1366.

Chaves MM (1991) Effects of water deficits on carbon assimilation. Journal of Experimental Botany 42, 1-16.

Chaves MM, Rodrigues ML (1987) Photosynthesis and water relations of grapevines growing in Portugal: response to environmental factors. In 'Plant response to stress: functional analysis in Mediterranean ecosystems'. (Eds JD Tenhunen, FM Catarino, OL Lange and WC Oechel) pp. 379-390. (Springer-Verlag: Berlin)

Chaves MM, Pereira JS, Maroco J, Rodrigues ML, Ricardo CPP, Osório ML, Carvalho I, Faria T, Pinheiro C (2002) How plants cope with water stress in the field. Photosynthesis and growth. Annals of Botany 89, 1-10.

Cornic G (2000) Drought stress inhibits photosynthesis by decreasing stomatal aperture - not by affecting ATP synthesis. Trends in Plant Science 5, 187-188.

Correia MJ, Chaves MM, Pereira JS (1990) Afternoon depression in photosynthesis in grapevine leaves: evidence for a high light stress effect. Journal of Experimental Botany 41, 417-426. 
Croker JL, Witte WT, Augé RM (1998) Stomatal sensitivity of six temperate, deciduous tree species to non-hydraulic root-to-shoot signalling of partial soil drying. Journal of Experimental Botany 49, 761-774.

Davies WJ, Zhang J (1991) Root signals and the regulation of growth and development of plants in drying soil. Annual Review of Plant Physiology and Plant Molecular Biology 42, 55-76.

Davies WJ, Tardieu F, Trejo CL (1994) How do chemical signals work in plants that grow in drying soil? Plant Physiology 104, 309-314.

Davies WJ, Bacon MA, Thompson DS, Sobeih W, Rodríguez LG (2000) Regulation of leaf and fruit growth in plants growing in drying soil: exploitation of the plants' chemical signalling system and hydraulic architecture to increase the efficiency of water use in agriculture. Journal of Experimental Botany 51, 1617-1626.

Di Marco G, Grego S, Tricoli D, Turi B (1977) Carbon isotope ratios $\left({ }^{13} \mathrm{C} /{ }^{12} \mathrm{C}\right)$ in fractions of field-grown grape. Physiologia Plantarum 41, 139-141.

dos Santos TP, Lopes CM, Rodrigues ML, de Souza CR, Maroco JP, Pereira JS, Silva JR, Chaves MM (2003). Partial rootzone drying: effects on growth and fruit quality of field-grown grapevines (Vitis vinifera). Functional Plant Biology 30, 663-671.

Dry P, Loveys BR (1998) Factors influencing grapevine vigour and the potential for control with partial rootzone drying. Australian Journal of Grape and Wine Research 4, 140-148.

Dry P, Loveys BR, Botting D, Düring H (1996) Effects of partial rootzone drying on grapevine vigour, yield, composition of fruit and use of water. In 'Proceedings of the 9th Australian wine industry technical conference'. (Eds CS Stockley, AS Sas, RA Johnstone and TH Lee) pp. 126-31. (Winetitles: Melbourne)

Dry PR, Loveys BR, Düring H (2000) Partial drying of the rootzone of grape. I. Transient changes in shoot growth and gas exchange. Vitis 39, 3-7.

Düring H, Loveys BR, Dry PR (1997) Root signals affect water use efficiency and shoot growth. Acta Horticulturae 427, 1-14.

Escalona JM, Flexas J, Medrano H (1999) Stomatal and non-stomatal limitations of photosynthesis under water stress in field-grown grapevines. Australian Journal of Plant Physiology 26, 421-433.

Farquhar GD, Richards RA (1984) Isotopic composition of plant carbon correlates with water use efficiency of wheat genotypes. Australian Journal of Plant Physiology 11, 539-552.

Farquhar GD, von Caemmerer S, Berry JA (1980) A biochemical model of photosynthesis $\mathrm{CO}_{2}$ assimilation in leaves of $\mathrm{C}_{3}$ plant species. Planta 149, 78-90.

Farquhar GD, O'Leary MH, Berry JA (1982) On the relationship between carbon isotope discrimination and the intercellular carbon dioxide concentration in leaves. Australian Journal of Plant Physiology 9, 121-137.

Flexas J, Badger M, Chow WS, Medrano H, Osmond CB (1999a) Analysis of the relative increase in photosynthetic $\mathrm{O}_{2}$ uptake when photosynthesis in grapevine leaves is inhibited following low night temperatures and/or water stress. Plant Physiology 121, 675-684.

Flexas J, Escalona JM, Medrano H (1999b) Water stress induces different levels of photosynthesis and electron transport rate regulation in grapevines. Plant, Cell and Environment 22, 39-48.

Gamon JA, Pearcy RW (1990) Photoinhibition in Vitis californica: interactive effects of sunlight, temperature and water status. Plant, Cell and Environment 13, 267-275.

Gibberd MR, Walker RR, Blackmore BH, Condon AG (2001) Transpiration efficiency and carbon isotope discrimination of grapevines grown under well-watered conditions in either glasshouse or vineyard. Australian Journal of Grape and Wine Research 7, 110-117.
Giménez D, Mitchell VJ, Lawlor D (1992) Regulation of photosynthesis rate of two sun flower hybrids under water stress. Plant Physiology 98, 516-524.

Gowing GJ, Davies WJ, Jones HG (1990) A positive root-sourced signal as an indicator of soil drying in apple, Malus domestica Borkh. Journal of Experimental Botany 41, 1535-1540.

Kliewer WM, Freeman BM, Hossom C (1983) Effect of irrigation, crop level and potassium fertilization on carignane vines. I. Degree of water stress and effect on growth and yield. American Journal of Enology and Viticulture 34, 186-196.

Krause GH, Weis E (1991) Chlorophyll fluorescence and photosynthesis: the basics. Annual Review of Plant Physiology and Plant Molecular Biology 42, 313-349.

Lawlor DW, Cornic G (2002) Photosynthetic carbon assimilation and associated metabolism in relation to water deficits in higher plants. Plant, Cell and Environment 25, 275-294.

Leegood RC (1995) Effects of temperature on photosynthesis and photorespiration. In 'Environment and plant metabolism: flexibility and acclimation'. (Ed. N Smirnoff) pp. 45-62. (Bios Scientific Publishers: Oxford)

Lopes C, Pinto PA (2000). Estimation de la surface foliaire principale et secondaire d'un sarment de vigne. Progrés Agricole et Viticole 117, 160-166.

Loveys BR (1984) Diurnal changes in water relations and abscisic acid in field grown Vitis vinifera cultivars III. The influence of xylem derived abscisic on leaf gas exchange. New Phytologist 98, 563-573.

Loveys BR, Dry PR, Stoll M, McCarthy MG (2000) Using plant physiology to improve the water efficiency of horticultural crops. Acta Horticulturae 537, 187-197.

Lu C, Zhang J (1999) Effects of water stress on photosystem II photochemistry and its thermostability in wheat plants. Journal of Experimental Botany 50, 1199-1206.

Maroco JP, Rodrigues ML, Lopes C, Chaves MM (2002) Limitations to leaf photosynthesis in field-grown grapevine under drought metabolic and modelling approaches. Functional Plant Biology 29, $1-9$.

Osório J, Osório ML, Chaves MM, Pereira JS (1998) Effects of water deficits on ${ }^{13} \mathrm{C}$ discrimination and transpiration efficiency of Eucalyptus globulus clones. Australian Journal of Plant Physiology 25, 645-653.

Prichard TL (1992) A volume balance approach to quality wine grape irrigation. In 'Viticultural practices'. (Eds MA Walker and WM Kliewer) pp. 12-23. (University of California Press: Davis)

Quick WP, Chaves MM, Wendler R, David M, Rodrigues ML, Passarinho JA, Pereira JS, Adcock MD, Leegood RC, Stitt M (1992) The effect of water stress on photosynthetic carbon metabolism in four species grown under field conditions. Plant, Cell and Environment 15, 25-35.

Schultz HR (1996) Water relations and photosynthesis responses of two grapevine cultivars of different geographical origin during water stress. Acta Horticulturae 427, 251-266.

Sharkey TD (1985) Photosynthesis in intact leaves of $\mathrm{C}_{3}$ plants: physics, physiology and rate limitations. Botanical Review 78, $71-75$.

Smart RE, Robinson JB, Due G, Brien CJ (1985) Canopy microclimate modification for the cultivar Shiraz II. Effects on must and wine composition. Vitis 24, 119-128.

Stoll M, Loveys B, Dry P (2000) Hormonal changes induced by partial rootzone drying of irrigated grapevine. Journal of Experimental Botany 51, 1627-1634.

Tardieu F, Zhang J, Davies WJ (1992) What information is conveyed by an ABA signal from maize roots in drying field soil? Plant, Cell and Environment 15, 185-191. 
Turner NC (1997) Further progress in crop water relations. Advances in Agronomy 58, 293-338.

Weis E, Berry J (1987) Quantum efficiency of photosystem II in relation to "energy-dependent quenching of chlorophyll fluorescence. Biochimica et Biophysica Acta 894, 198-208.

Zhang J, Davies WJ (1989a) Abscisic acid produced in dehydrating roots may enable the plant to measure the water status of the soil. Plant Cell and Environment 12, 73-81.
Zhang J, Davies WJ (1989b) Sequential response of whole plant water reactions to prolonged soil drying and the involvement of xylem sap $A B A$ in the regulation of stomatal behaviour of sunflower plants. New Phytologist 113, 167-174.

Manuscript received 13 June 2002, received in revised form 30 September 2002, accepted 6 November 2002 